\title{
HIGH CONTRIBUTION OF RECALCITRANT ORGANIC MATTER TO DOC IN A JAPANESE OLIGOTROPHIC LAKE REVEALED BY ${ }^{14} \mathrm{C}$ MEASUREMENTS
}

\author{
Fumiko Watanabe Nara ${ }^{1,2} \cdot$ Akio Imai $^{1} \cdot$ Masao Uchida $^{1} \cdot$ Kazuo Matsushige $^{1} \bullet$ \\ Kazuhiro Komatsu ${ }^{1}$ - Nobuyuki Kawasaki ${ }^{1}$ Y Yasuyuki Shibata ${ }^{1} \cdot$ Kunihiko Amano $^{3} \bullet$ \\ Hajime Mikami ${ }^{4}$ Ryuji Hanaishi ${ }^{4}$
}

\begin{abstract}
Carbon isotopes $\left({ }^{14} \mathrm{C}\right.$ and ${ }^{13} \mathrm{C}$ ) of dissolved organic carbon (DOC) in a Japanese oligotrophic lake (Lake Towada) were measured to study the origin and cycling of dissolved organic matter (DOM) in Lake Towada. Lake water samples were collected at 3 depths $\left(0,30\right.$, and 80 or $85 \mathrm{~m}$ ) during 4 months (April, June, August, and October) in $2006 .{ }^{14} \mathrm{C}$ measurements of DOC were performed by accelerator mass spectrometry (AMS) at the National Institute for Environmental Studies (NIES-TERRA) in Japan. $\Delta^{14} \mathrm{C}$ and $\delta^{13} \mathrm{C}$ values of DOC in Lake Towada showed light carbon isotopic values ranging from -750 to $-514 \%$ and -29.0 to $-27.8 \%$, respectively. These values are similar to those of humic substances reported. The very low carbon isotopic values of DOC in Lake Towada suggest a very small contribution of DOC derived from fresh phytoplankton to the lake DOC. There is an extremely high linear relationship between the $\Delta^{14} \mathrm{C}$ and $\delta^{13} \mathrm{C}$ of DOC in Lake Towada when all data points are plotted $\left(r^{2}=0.818, p<0.01\right)$, suggesting that the DOC in Lake Towada has 2 specific sources contributing heavy and light carbon isotopes. Although the freshly produced DOC of phytoplankton origin can be decomposed easily, the variation in the autochthonous DOC should influence the carbon isotopic values of DOC in Lake Towada.
\end{abstract}

\section{INTRODUCTION}

Lake Towada is located in northern Japan $\left(40^{\circ} 28^{\prime} \mathrm{N}, 140^{\circ} 53^{\prime} \mathrm{E}\right)$, and is well known as an oligotrophic lake with highly transparent water (around $12 \mathrm{~m}$ year-round) in Japan. Because of the beautiful surroundings around Lake Towada, the lake is famous as a tourist resort and has been designated as a national park by the Japanese government. A gradual increase in dissolved chemical oxygen demand (COD) in Lake Towada has been reported (Mikami et al. 2001), although special efforts for reducing the nutrient load from influent rivers to Lake Towada have been carried out.

The gradual increases in COD in lake water from 1980s have been observed at other Japanese lakes regardless of the nutritional state of the lake (Imai et al. 2007). Furthermore, long-term increases in DOC in river drainage areas of upland UK and US lakes have been also reported (Freeman et al. 2001; Driscoll et al. 2003; Worrall et al. 2004a,b, 2007). Worrall et al. (2004b) showed long-term increases in DOC at 29 lakes and at 161 rivers in the UK. These results indicate that the long-term increases in DOC concentration became a ubiquitous phenomenon of inland water. Although the change in $\mathrm{pH}$ and increase in temperature are pointed out as important factors for the increase in DOC in lake environments (Driscoll et al. 2003; Worrall et al. 2004a), it is still unclear the reason why DOC in lake environments has been increasing (Worrall et al. 2004a). To clarify the mechanisms of the increase in DOC in lake environments, it is necessary to understand the origin of DOC in lake water.

Paired carbon isotope measurements $\left(\Delta^{14} \mathrm{C}\right.$ and $\left.\delta^{13} \mathrm{C}\right)$ have been used as an effective tool for estimating the carbon source of dissolved organic matter in lake and marine environments (McCallister et al. 2004). The objective of this study is to evaluate the source and ages of DOC in Lake Towada using a $\Delta^{14} \mathrm{C}$ and $\delta^{13} \mathrm{C}$ approach. Vertical and seasonal measurements of carbon isotopes $\left(\Delta^{14} \mathrm{C}\right.$ and $\delta^{13} \mathrm{C}$ ) for DOC may allow us to estimate the source and cycling of DOC in the lake.

\footnotetext{
${ }^{1}$ National Institute for Environmental Studies, 16-2 Onogawa, Tsukuba, Ibaraki 305-8506, Japan.

${ }^{2}$ Corresponding author. Email: fumiko.watanabe@ulg.ac.be.

${ }^{3}$ Public Works Research Institute, 1-6 Minamihara, Tsukuba, Ibaraki 305-8516, Japan.

${ }^{4}$ Aomori Prefectural Institute of Public Health and Environment, Aomori, Aomori 030-8566, Japan.
}

C 2010 by the Arizona Board of Regents on behalf of the University of Arizona Proceedings of the 20th International Radiocarbon Conference, edited by A J T Jull RADIOCARBON, Vol 52, Nr 2-3, 2010, p 1078-1083 


\section{SAMPLE COLLECTION AND ANALYTICAL METHODS}

Lake water samples were collected at the center of the lake in April, June, August, and October 2006 (Figure 1). The depths of collection were at 0,30 , and $80 \mathrm{~m}$. Water samples were filtered through a precombusted $\left(45^{\circ} \mathrm{C}\right.$ for $\left.4 \mathrm{hr}\right)$ Whattman GF/F filter $(0.7-\mu \mathrm{m}$ pore size $)$ and stored at $-30{ }^{\circ} \mathrm{C}$. The powdered samples of DOC for carbon isotopic analysis were obtained by freeze-drying and treated with $6 \mathrm{M} \mathrm{HCl}$ to remove inorganic carbonate prior to isotopic measurement.

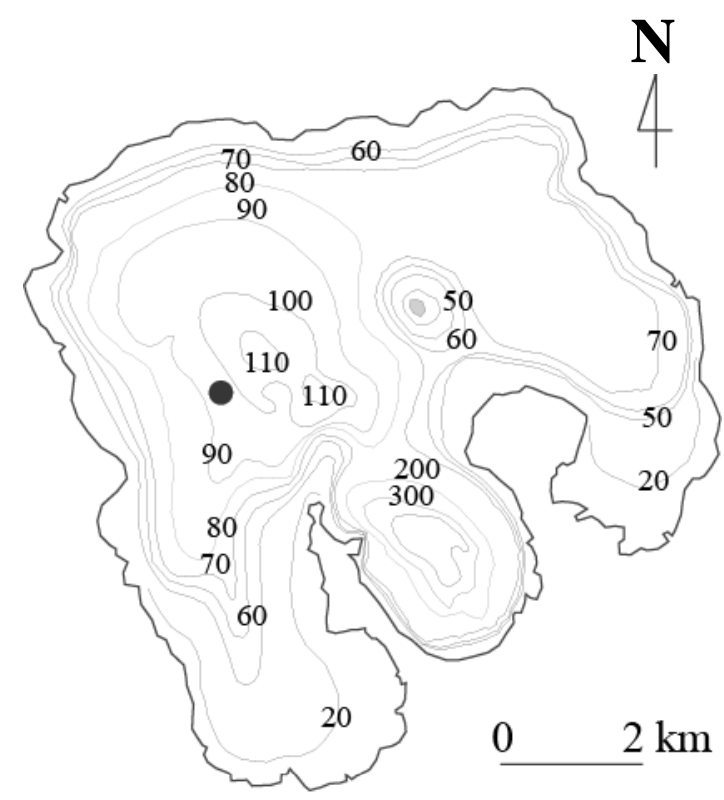

Figure 1 Map showing the sampling site of Lake Towada

Before ${ }^{14} \mathrm{C}$ analysis by accelerator mass spectrometry (AMS), purified $\mathrm{CO}_{2}$ gases of the samples were prepared in a system with an elemental analyzer connected to cryogenic traps (EA-CT) (Yoneda et al. 2004). The purified $\mathrm{CO}_{2}$ was catalytically reduced to graphite with $\mathrm{H}_{2}$ over Fe. ${ }^{14} \mathrm{C}$ analysis of the graphite target was conducted at the AMS facility of the National Institute for Environmental Studies (NIES-TERRA), Japan. The uncertainty regarding these ${ }^{14} \mathrm{C}$ measurements was generally less than $0.6 \mathrm{pMC}$.

$\delta^{13} \mathrm{C}$ values of the DOC were measured using an elemental analyzer (Thermo Flash 1112 series) interfaced to an isotopic ratio mass spectrometer (Thermo Delta X Advantage) via a Conflo III split interface. Carbon isotopic composition was calibrated using a laboratory organic carbon standard (L-alanine: Shoko-tsusho, $\left.\delta^{13} \mathrm{C}=-19.03 \%\right)$ and expressed as per mil (\%o) relative to Vienna Pee Dee belemnite (VPDB). Standard deviations of the $\delta^{13} \mathrm{C}$ measurements for DOC in duplicated analyses were generally $<0.1 \%$.

\section{RESULTS AND DISCUSSION}

\section{$\triangle^{14} \mathrm{C}$ and $\delta^{13} \mathrm{C}$ Values of DOC in Lake Towada}

$\Delta^{14} \mathrm{C}$ and $\delta^{13} \mathrm{C}$ values of DOC in Lake Towada ranged from -749 to $-515 \%$ and -29.0 to $-27.9 \%$, respectively (Table 1). The lightest and heaviest carbon isotopic values $\left(\Delta^{14} \mathrm{C}\right.$ and $\left.\delta^{13} \mathrm{C}\right)$ were 
observed at surface water on June and at $85 \mathrm{~m}$ depth on August, respectively. Interestingly, the lightest carbon isotope values of DOC in the surface water in June have the highest DOC concentration.

Table 1 Dissolved organic carbon (DOC) concentration, $\delta^{13} \mathrm{C}$, pMC, $\Delta{ }^{14} \mathrm{C}$, and conventional ${ }^{14} \mathrm{C}$ age results for Lake Towada.

\begin{tabular}{lcllllrl}
\hline Sampling date & $\begin{array}{l}\text { Depth } \\
(\mathrm{cm})\end{array}$ & $\begin{array}{l}\text { DOC } \\
(\mathrm{mg} \mathrm{C} / \mathrm{L})\end{array}$ & $\begin{array}{l}\delta^{13} \mathrm{C} \\
(\%)\end{array}$ & $\begin{array}{l}\text { pMC } \\
(\%)\end{array}$ & $\begin{array}{l}\Delta^{14} \mathrm{C} \\
(\%)\end{array}$ & \multicolumn{1}{l}{$\begin{array}{l}\text { Age } \\
(\mathrm{yr} \mathrm{BP})\end{array}$} & $\begin{array}{l}\text { Lab code } \\
\text { (TERRA-) }\end{array}$ \\
\hline 19 April 2006 & 0 & 0.685 & -28.3 & 38.8 & -612 & $7608 \pm 41$ & $112108 \mathrm{a} 20$ \\
& 30 & 0.606 & -28.4 & 33.5 & -665 & $8774 \pm 44$ & $112108 \mathrm{a} 24$ \\
& 85 & 0.620 & -28.7 & 32.3 & -677 & $9086 \pm 42$ & $112108 \mathrm{a} 25$ \\
21 June 2006 & 0 & 0.841 & -29.0 & 25.1 & -749 & $11,115 \pm 47$ & $112108 \mathrm{a} 23$ \\
& 30 & 0.665 & -28.6 & 31.6 & -684 & $9259 \pm 44$ & $112108 \mathrm{a} 26$ \\
& 85 & 0.689 & -28.3 & 36.9 & -631 & $8002 \pm 56$ & $121508 \mathrm{a} 10$ \\
23 August 2006 & 0 & 0.730 & -28.1 & 45.1 & -549 & $6396 \pm 38$ & $112108 \mathrm{a} 28$ \\
& 30 & 0.765 & -27.9 & 48.5 & -515 & $5809 \pm 38$ & $112108 \mathrm{a} 29$ \\
& 85 & 0.652 & -28.1 & 36.8 & -632 & $8027 \pm 51$ & $121708 \mathrm{a} 04$ \\
& 0 & 0.673 & -28.5 & 37.8 & -622 & $7805 \pm 40$ & $112108 \mathrm{a} 30$ \\
& 30 & 0.704 & -28.6 & 35.0 & -650 & $8431 \pm 49$ & $121508 \mathrm{a} 15$ \\
& 85 & 0.720 & -28.5 & 36.6 & -634 & $8078 \pm 63$ & $121508 \mathrm{a} 06$ \\
\hline
\end{tabular}

Compared to other DOC studies of $\Delta^{14} \mathrm{C}$ measurements, the $\Delta^{14} \mathrm{C}$ values of this study showed low carbon isotopic values (e.g. Raymond and Bauer 2001). The water residence time of Lake Towada was $\sim 8$ yr (Mikami et al. 2001). Nevertheless, the ${ }^{14} \mathrm{C}$ ages of DOC in this study were more than $5000 \mathrm{yr}$ old (Table 1). The recalcitrant organic matter, which is biologically inert, plays an important role in the DOC in Lake Towada.

The inflow of old dissolved inorganic carbon (DIC) to Lake Towada is one of the possible reasons for old DOC in Lake Towada. However, because Lake Towada is a caldera lake, the lakeshore and lake basin of Lake Towada are composed of silicate rock, such as granite and basalt. The possibility of inflowing dead carbon from old carbonate rocks should be rejected. On the other hand, old carbon in freshwater could be induced by the carbon reservoir effect resulting from inflow of melting glacier or the reproduction of inorganic carbon in lake environments (Moreton et al. 2004). As noted above, the residence time of Lake Towada is within $10 \mathrm{yr}$. The carbon reservoir effect in Lake Towada is still not enough for the explanation of old DOC in this study.

The $\delta^{13} \mathrm{C}$ values of DOC in Lake Towada are lower compared to other lakes and seawater (Guo et al. 1996). The range of $\delta^{13} \mathrm{C}$ values of DOC in Lake Towada ( -29.0 to $-27.9 \%$ ) was similar to that of terrestrial $\mathrm{C}_{3}$ plants ( $-27 \%$ on average) rather than that of phytoplankton (Gu et al. 1996; Nelson et al. 2007).

\section{Vertical Profiles of $\Delta^{14} \mathrm{C}$ and $\delta^{13} \mathrm{C}$ Values of DOC in Lake Towada}

The vertical profiles of each parameter $\left(\Delta^{14} \mathrm{C}\right.$ and $\delta^{13} \mathrm{C}$ values of DOC, water temperature and dissolved oxygen [DO]) are shown in Figure 2. In summer and autumn (June, August, and October 2006), the lake water was stratified (Figure 2). On the other hand, in spring (April), the water temperature was constant $\left(4^{\circ} \mathrm{C}\right)$, and the lake water was mixed well vertically.

The vertical profile of DO showed the opposite profile than that of water temperature (Figure 2). These profiles indicate that the DO contents in Lake Towada were determined by water solubility, which depends on the water temperature. The DO content measured at $85 \mathrm{~m}$ in 2006 was more than 
$10 \mathrm{mg} / \mathrm{g}$ of DO. Thus, the DO in Lake Towada has been abundant in the bottom waters throughout the year, although the lake water was stratified.

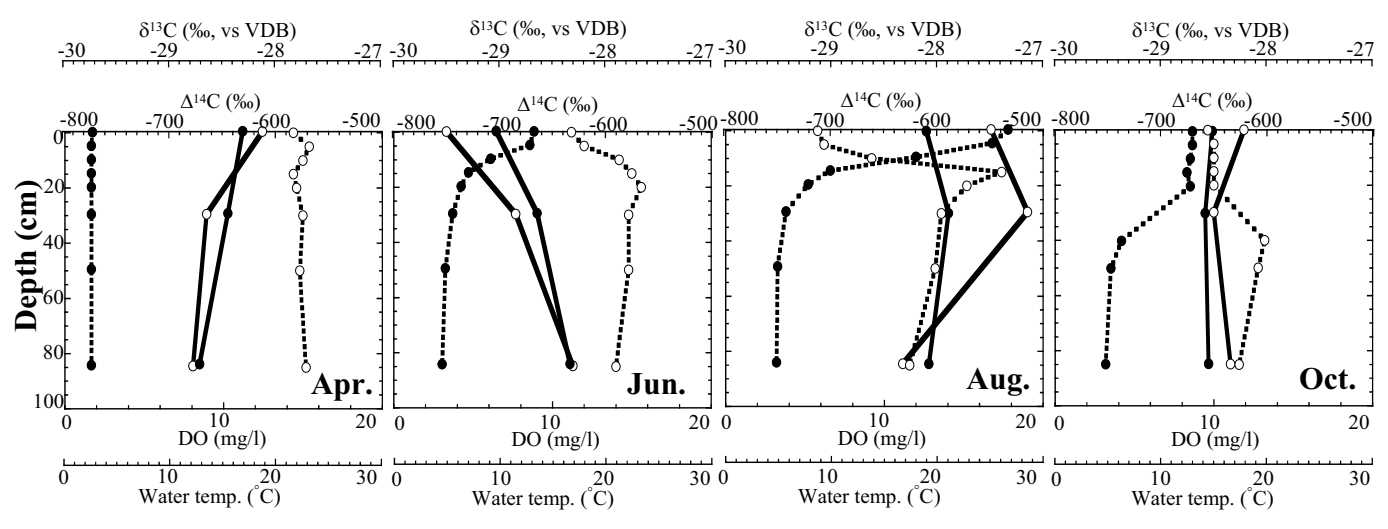

Figure 2 Vertical profiles of $\Delta^{14} \mathrm{C}$ and $\delta^{13} \mathrm{C}$ values of DOC, water temperature, and dissolved oxygen in Lake Towada

The $\Delta^{14} \mathrm{C}$ and $\delta^{13} \mathrm{C}$ values of DOC in the surface water showed wide isotopic ranges ( \pm 84 and \pm 0.40 for $\Delta^{14} \mathrm{C}$ and $\delta^{13} \mathrm{C}$, respectively). On the other hand, the range of $\Delta^{14} \mathrm{C}$ and $\delta^{13} \mathrm{C}$ values of DOC at the bottom water $\left(85 \mathrm{~m}\right.$ ) were \pm 23 and \pm 0.28 for $\Delta^{14} \mathrm{C}$ and $\delta^{13} \mathrm{C}$, respectively (Figure 3 ). These results indicate that the DOC in the surface water could not be transported to the bottom water in summer and autumn because of the stratification of lake water. In June and August, the $\Delta^{14} \mathrm{C}$ and $\delta^{13} \mathrm{C}$ values of DOC at $30 \mathrm{~m}$ depth in Lake Towada showed lighter carbon isotopic values than those of surface water. These results imply that the autochthonous organic matter could affect DOC at the $30 \mathrm{~m}$ depth rather than at the surface.

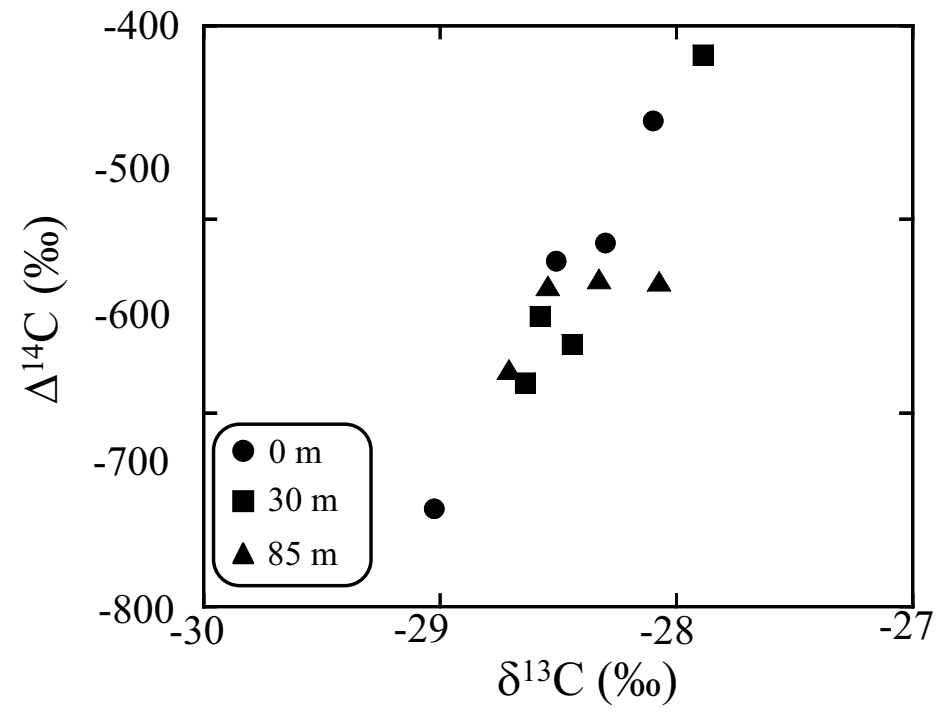

Figure 3 Correlation between $\Delta^{14} \mathrm{C}$ and $\delta^{13} \mathrm{C}$ values of DOC 


\section{Source of DOC in Lake Towada Inferred from $\Delta^{14} \mathrm{C}$ and $\delta^{13} \mathrm{C}$ Values}

There is an extremely high linear relationship between the $\Delta^{14} \mathrm{C}$ and $\delta^{13} \mathrm{C}$ of DOC in Lake Towada when all data points are plotted $\left(r^{2}=0.818, p<0.01\right)$ (Figure 3 ). This result indicates that the DOC in Lake Towada has 2 specific sources comprising heavy and light carbon isotopes. The decomposition of DOC is also a plausible factor for the change of carbon isotopic values (Cherrier et al. 1999; Freeman et al. 2001). However, there were no correlations between $\Delta{ }^{14} \mathrm{C}$ and DOC content and $\delta^{13} \mathrm{C}$ and DOC content (Figure 4). Therefore, the source of DOC in Lake Towada could be determined by the mixture between autochthonous and allochthonous organic matter.

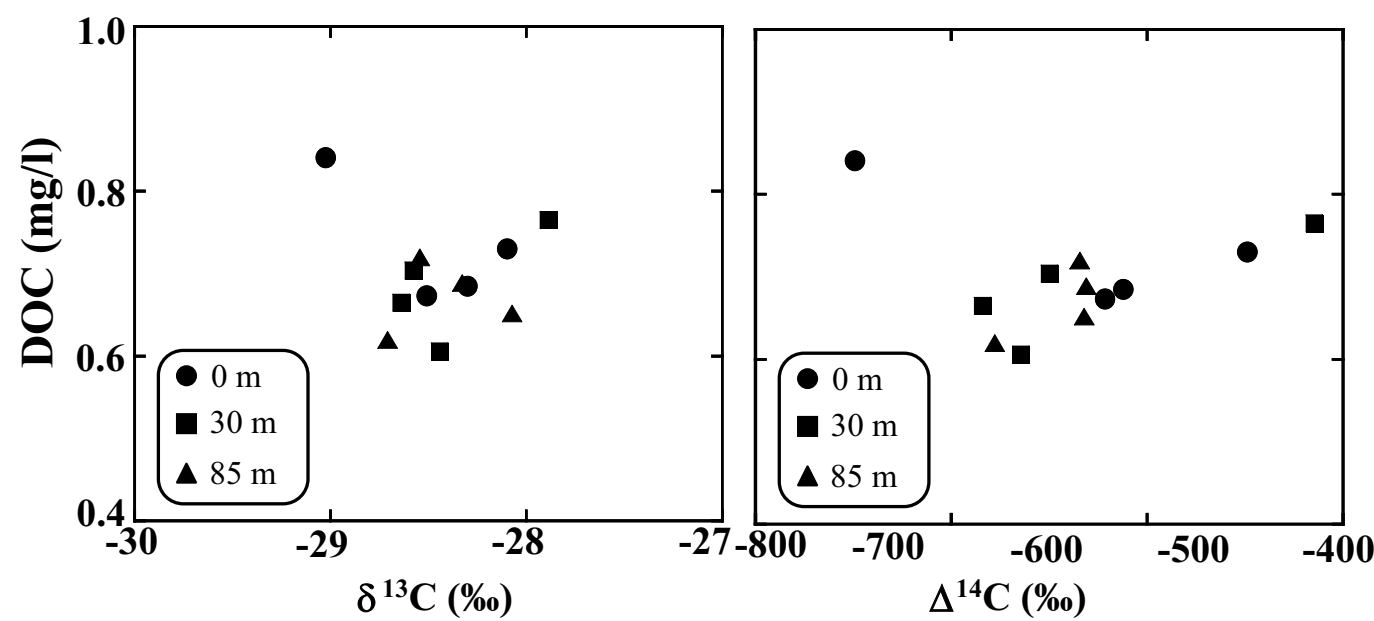

Figure 4 Correlation between $\Delta^{14} \mathrm{C}$ and DOC content, and $\delta^{13} \mathrm{C}$ and DOC content

\section{CONCLUSION}

We have collected water samples to estimate the DOC source in Lake Towada. The $\Delta^{14} \mathrm{C}$ and $\delta^{13} \mathrm{C}$ values of DOC indicate that terrestrial organic matter plays an important role in Lake Towada, and the contributions of autochthonous organic matter for DOC were negligible. The high linear relationship between $\Delta^{14} \mathrm{C}$ and $\delta^{13} \mathrm{C}$ values of DOC indicates that the source of DOC in Lake Towada could be determined by the mixture of autochthonous and allochthonous organic matter.

\section{ACKNOWLEDGMENTS}

We thank Toshiyuki Kobayashi and Ryo Suzuki for the ${ }^{14} \mathrm{C}$ measurements at NIES-TERRA. This work was supported in part by a Grant-In-Aid for Scientific Research for Young Scientists (B) to F N (No. 18740299) from the Ministry of Education, Science, Sports and Culture, Japan.

\section{REFERENCES}

Cherrier J, Bauer JE, Druffel ERM, Coffin RB, Chanton JP. 1999. Radiocarbon in marine bacteria: evidence for the ages of assimilated carbon. Limnology and Oceanography 44(3):730-6.

Driscoll CT, Driscoll KM, Roy KM, Mitchell MJ. 2003. Chemical response of lakes in the Adirondack region of New York to declines in acidic deposition. Environmental Science and Technology 37(10):2036-42.
Freeman C, Evans CD, Monteith DT, Reynolds B, Fenner N. 2001. Export of organic carbon from peat soils. Nature 412(6849):785-6.

Guo L, Santschi PH, Cifuentes LA, Trumbore SE, Southon J. 1996. Cycling of high-molecular-weight dissolved organic matter in the Middle Atlantic Bight as revealed by carbon isotopic $\left({ }^{13} \mathrm{C}\right.$ and $\left.{ }^{14} \mathrm{C}\right)$ signature. Limnology and Oceanography 41(6):1242-52. 
Gu B, Schelske CL, Brenner M. 1996. Relationship between sediment and plankton isotope ratios $\left(\delta^{13} \mathrm{C}\right.$ and $\delta^{15} \mathrm{~N}$ ) and primary productivity in Florida lakes. $\mathrm{Ca}$ nadian Journal of Fisheries and Aquatic Sciences 53: 875-83.

Imai A. 2007. Report of special research from the National Institute for Environmental Studies, Japan. Tsukuba: NIES. In Japanese.

McCallister SL, Bauer JE, Cherrier JE, Ducklow HW. 2004. Assessing sources and ages of organic matter supporting river and estuarine bacterial production: a multiple isotope $\left(\Delta^{14} \mathrm{C}, \delta^{13} \mathrm{C}\right.$, and $\left.\delta^{15} \mathrm{~N}\right)$ approach. Limnology and Oceanography 49(5):1687-702.

Mikami H, Sakazaki T, Kudo I, Nozawa H, Jin T, Kon T, Maeda T. 2001. Nutrient loadings to Lake Towada during 1999-2000. In: Nakamura T, editor. Ecosystem Management Studies in Lake Towada II. Tsukuba: National Institute for Environmental Studies. p 1-14. In Japanese.

Moreton SG, Rosqvist GC, Davies SJ, Bentley MJ. 2004. Radiocarbon reservoir ages from freshwater lakes, south Georgia, sub-Antarctic: modern analogues from particulate organic matter and surface sediments. $R a$ diocarbon 46(2):621-6.

Nelson DM, Hu FS, Mikucki JA, Tian J, Pearson A. 2007. Carbon-isotopic analysis of individual pollen grains from $\mathrm{C}_{3}$ and $\mathrm{C}_{4}$ grasses using a spooling-wire microcombustion interface. Geochimica et Cosmochimica Acta 71(16):4005-14.

Raymond PA, Bauer JE. 2001. Riverine export of aged terrestrial organic matter to the North Atlantic Ocean. Nature 409(6819):497-9.

Worrall F, Burt T, Adamson J. 2004a. Can climate change explain increases in DOC flux from upland peat catchments? Science of the Total Environment 326(1-3): 95-112.

Worrall F, Harriman R, Evans CD, Watts CD, Adamson J, Neal C, Tipping E, Burt T, Grieve I, Monteith D, Naden PS, Nisbet T, Reynolds B, Stevens P. 2004b. Trends in dissolved organic carbon in UK rivers and lakes. Biogeochemistry 70(3):369-402.

Worrall F, Gibson HS, Burt TP. 2007. Modelling the impact of drainage and drain-blocking on dissolved organic carbon release from peatlands. Journal of $\mathrm{Hy}$ drology 338(1-2):15-27.

Yoneda M, Shibata Y, Tanaka A, Uehiro T, Morita M, Uchida M, Kobayashi T, Kobayashi C, Suzuki R, Miyamoto K, Hancock B, Dibden C, Edmonds JS. 2004. AMS ${ }^{14} \mathrm{C}$ measurement and preparative techniques at NIES-TERRA. Nuclear Instruments and Methods in Physics Research B 223-224:116-23. 